\section{Bilateral Parsonage-Turner Syndrome After Initial Unilateral Presentation: A Case Report}

\author{
Brendan Lindgren ${ }^{1}$, Dustin Rivers ${ }^{2}$, Jeffrey Clark ${ }^{2}$ \\ 1. Neurology, Northwell Health, Riverhead, USA 2. Neurology, Baylor Scott and White, Temple, USA
}

Corresponding author: Brendan Lindgren, brendan.t.lindgren@gmail.com
Received 10/19/2019

Review began 11/06/2019 Review ended 12/15/2019 Published 12/19/2019

\section{() Copyright 2019}

Lindgren et al. This is an open access article distributed under the terms of the Creative Commons Attribution License CC-BY 3.0., which permits unrestricted use, distribution, and reproduction in any medium, provided the original author and source are credited.

\begin{abstract}
Parsonage-Turner syndrome (PTS) is a clinical syndrome characterized by rapid onset of upper extremity pain typically followed by varying degrees of weakness and atrophy. In this case, we discuss a 54-year-old female who developed severe right upper extremity pain soon after receiving a shingles vaccine, which was then followed by weakness and atrophy. Thorough medical workup was unrevealing, as it was too early to see electromyography (EMG) changes. Nine months later she presented to the hospital again with a similar presentation of the contralateral upper extremity. EMG findings at that time were supportive of a PTS diagnosis. This report discusses the clinical variability, etiology, and treatment of PTS, as well as some diagnostic complexities and how they were overcome to diagnose this patient.
\end{abstract}

Categories: Neurology, Physical Medicine \& Rehabilitation, Neurosurgery

Keywords: brachial neuritis, shoulder pain, functional disorders, neurogenic amyotrophy, upper extremity weakness, parsonage-turner syndrome, shingles vaccine, idiopathic brachial plexopathy, acute brachial neuropathy, brachial plexitis

\section{Introduction}

Parsonage-Turner syndrome (PTS), brachial neuritis, idiopathic brachial plexopathy, and neurogenic amyotrophy are some of the many terms that refer to the same clinical syndrome that is characterized by rapid onset of upper extremity pain typically followed by varying degrees of weakness and atrophy. Beyond that, the clinical syndrome is highly variable. The distribution of nerves affected can vary from anything between an isolated mononeuropathy in the upper extremity and the entire bilateral brachial plexus, possibly in combination with the lumbosacral plexus, phrenic nerve, cranial nerves, and/or other peripheral nerves [1]. With that in mind, nearly any distribution of weakness or sensory symptoms can be found, though some distributions are certainly more common than others. While an initial period of pain is almost invariably present and lasts around four weeks on average, it can last less than one week in $5 \%$ or greater than two months in $10 \%$ [2]. Recovery of strength also varies considerably from patient to patient. By the end of year 3, most patients recover $80 \%-90 \%$ of their strength, but greater than $70 \%$ are left with residual weakness and exercise intolerance [1]. The exact cause of this disorder is unknown, but greater than $50 \%$ report an immunologic event before the episode, certain mutations (SEPT9) appear to make patients more prone to it, and nearly $10 \%$ are preceded by unusual exercise [1].

\section{Case Presentation}

A 54-year-old right-hand dominant female chef at a local university presented with severe bilateral upper extremity weakness and sensory changes. Approximately nine months earlier, she had developed right upper extremity (RUE) pain a few days after receiving a shingles vaccine, which was quickly followed by RUE weakness. She saw an outside neurologist at that time, and after an extensive workup that included magnetic resonance imaging (MRI), electromyography (EMG), nerve conduction studies (NCS), and lumbar puncture (LP), no organic cause was discovered, and based on her clinical examination a functional disorder was suspected (giveway/collapsing weakness). Five months later, a similar series of symptoms occurred in the left upper extremity (pain followed by weakness). No further workup was done at that time, and she did not receive treatment due to the belief that her symptoms were psychogenic. Despite spontaneous resolution of pain, she presented to the emergency room for persistent weakness four months later (nine months after the initial event involving the RUE).

On physical examination during her most recent admission, profound symmetric weakness was noted in her bilateral upper extremities. The weakness was more severe proximally ( $2 / 5$ strength in deltoids; $3 / 5$ biceps, triceps, wrist extensors, wrist flexors, and intrinsic hand muscles; $4 / 5$ finger flexors and extensors), and significant atrophy of the bilateral shoulders was noted. Her upper extremity reflexes (biceps, triceps, brachioradialis) were absent bilaterally, with preservation of her lower extremity reflexes. Sensation to pinprick, light touch, vibration, and temperature were diminished symmetrically up to the shoulder in her bilateral upper extremities.

During her most recent admission, she received an evaluation that included MRI with gadolinium of the brain, cervical spine, thoracic spine, and brachial plexus, along with LP (Table 5), EMG (Tables 1, 2), and NCS 


\section{Cureus}

(Tables 3, 4). The MRI brain, cervical spine, thoracic spine, and LP revealed no contributory findings to her clinical symptoms. EMG of her bilateral upper extremities revealed evidence of an active denervating process involving $\mathrm{C} 5$ through $\mathrm{T} 1$ distribution in both upper extremities. No genetic testing was done, but she denied any family history of similar symptoms. Results in Tables 1-5 are all from her final admission.

\begin{tabular}{|l|l|l|l|l|l|l|l|l|l|}
\hline Nerve & $\begin{array}{l}\text { Min M Lat } \\
(\mathrm{ms})\end{array}$ & $\begin{array}{l}\text { Max M Lat } \\
(\mathrm{ms})\end{array}$ & $\begin{array}{l}\text { Mean M Lat } \\
(\mathrm{ms})\end{array}$ & $\begin{array}{l}\text { Min M Amp } \\
(\mathrm{mV})\end{array}$ & $\begin{array}{l}\text { Max M Amp } \\
(\mathrm{mV})\end{array}$ & $\begin{array}{l}\text { Mean M Amp } \\
(\mathrm{mV})\end{array}$ & $\begin{array}{l}\text { Min F Lat } \\
(\mathrm{ms})\end{array}$ & $\begin{array}{l}\text { Max F Lat } \\
(\mathrm{ms})\end{array}$ & $\begin{array}{l}\text { Mean F Lat } \\
(\mathrm{ms})\end{array}$ \\
\hline R Ulnar & 2.81 & 2.97 & 2.89 & 7.31 & 7.71 & 7.45 & 27.86 & 28.23 & 28.00 \\
\hline $\begin{array}{l}\text { R Tibial } \\
\text { (foot) }\end{array}$ & 5.26 & 5.36 & 5.31 & 7.72 & 8.12 & 7.92 & 50.26 & 52.50 & 51.41 \\
\hline
\end{tabular}

TABLE 1: Electromyography F Wave

Amp $=$ amplitude, Lat $=$ latency 


\section{Cureus}

\begin{tabular}{|c|c|c|c|c|c|c|c|c|c|c|c|c|}
\hline \multicolumn{13}{|l|}{ EMG Summary Table } \\
\hline \multirow[b]{2}{*}{ Muscle } & \multirow[b]{2}{*}{ Nerve } & \multirow[b]{2}{*}{ Roots } & \multicolumn{5}{|c|}{ Spontaneous } & \multicolumn{3}{|c|}{ MUAP } & \multicolumn{2}{|l|}{ Recruitment } \\
\hline & & & IA & Fib & PSW & Fasc & H.F. & Amp & Dur & PPP & Pattern & Comments \\
\hline R. Deltoid & Axillary & $\begin{array}{l}\mathrm{C} 5- \\
\mathrm{C} 6\end{array}$ & $\mathrm{~N}$ & $2+$ & $2+$ & None & None & $\mathrm{N}$ & $\mathrm{N}$ & $\mathrm{N}$ & Markedly RIFP & LDP \\
\hline R. Biceps brachii & Musculocutaneous & $\begin{array}{l}\mathrm{C5}- \\
\mathrm{C} 6\end{array}$ & $\mathrm{~N}$ & $2+$ & $3+$ & None & None & $\mathrm{N}$ & $\mathrm{N}$ & $\mathrm{N}$ & $\mathrm{N}$ & $\begin{array}{l}\text { No Vol } \\
\text { units }\end{array}$ \\
\hline R. Triceps brachii & Radial & $\begin{array}{l}\mathrm{C} 6- \\
\mathrm{C} 8\end{array}$ & $\mathrm{~N}$ & $1+$ & $2+$ & None & None & $\mathrm{N}$ & $\mathrm{N}$ & $\mathbf{N}$ & $\mathrm{N}$ & None \\
\hline $\begin{array}{l}\text { R. Extensor carpi radialis } \\
\text { longus }\end{array}$ & Radial & $\begin{array}{l}\mathrm{Cb}- \\
\mathrm{C} 6\end{array}$ & $\mathrm{~N}$ & $2+$ & $2+$ & None & None & $\mathrm{N}$ & $\mathrm{N}$ & $\mathrm{N}$ & Markedly RIFP & LD \\
\hline $\begin{array}{l}\text { R. First dorsal } \\
\text { interosseous }\end{array}$ & Ulnar & $\begin{array}{l}\text { C8- } \\
\text { T1 }\end{array}$ & $\mathrm{N}$ & $2+$ & $3+$ & None & None & $\mathrm{N}$ & $\mathrm{N}$ & $\mathrm{N}$ & RIFP & LD/LDP \\
\hline R. Quadriceps & Femoral & L2-L4 & $\mathrm{N}$ & None & None & None & None & $\mathrm{N}$ & $\mathrm{N}$ & $\mathrm{N}$ & $\mathrm{N}$ & None \\
\hline R. Tibialis anterior & $\begin{array}{l}\text { Deep peroneal } \\
\text { (fibular) }\end{array}$ & L4-L5 & $\mathrm{N}$ & None & None & None & None & $\mathrm{N}$ & $\mathrm{N}$ & $\mathrm{N}$ & $\mathrm{N}$ & None \\
\hline $\begin{array}{l}\text { R. Gastrocnemius (medial } \\
\text { head) }\end{array}$ & Tibial & $\begin{array}{l}\mathrm{S} 1- \\
\mathrm{S} 2\end{array}$ & $\mathrm{~N}$ & None & None & None & None & $\mathrm{N}$ & $\mathrm{N}$ & $\mathrm{N}$ & $\mathrm{N}$ & RIFP \\
\hline L. Deltoid & Axillary & $\begin{array}{l}\mathrm{C} 5- \\
\mathrm{C} 6\end{array}$ & $\mathrm{~N}$ & $1+$ & $2+$ & None & None & $\mathrm{N}$ & $\mathrm{N}$ & $\mathrm{N}$ & $\begin{array}{l}\text { Single unit } \\
\text { interference } \\
\text { pattern }\end{array}$ & None \\
\hline L. Biceps brachii & Musculocutaneous & $\begin{array}{l}\mathrm{C} 5- \\
\mathrm{C} 6\end{array}$ & $\mathrm{~N}$ & $3+$ & $3+$ & None & None & $\mathrm{N}$ & $\mathrm{N}$ & $\mathrm{N}$ & $\begin{array}{l}\text { Single unit } \\
\text { interference } \\
\text { pattern }\end{array}$ & None \\
\hline L Triceps brachii & Radial & $\begin{array}{l}\text { C6- } \\
\text { C8 }\end{array}$ & $\mathrm{N}$ & $1+$ & $2+$ & None & None & $\mathrm{N}$ & $\mathrm{N}$ & $\mathrm{N}$ & Markedly RIFP & LDP \\
\hline $\begin{array}{l}\text { L First dorsal } \\
\text { interosseous }\end{array}$ & Ulnar & $\begin{array}{l}\text { C8- } \\
\text { T1 }\end{array}$ & $\mathrm{N}$ & $2+$ & $2+$ & None & None & $\mathrm{N}$ & $\mathrm{N}$ & $\mathrm{N}$ & RIFP & $\begin{array}{l}\mathrm{NL} \\
\mathrm{LD} / \mathrm{LDP}\end{array}$ \\
\hline R. Cervical paraspinals & Spinal & $\begin{array}{l}\text { C4- } \\
\mathrm{C} 8\end{array}$ & $\mathrm{~N}$ & None & None & None & None & $\mathbf{N}$ & $\mathrm{N}$ & $\mathrm{N}$ & $\mathbf{N}$ & $\begin{array}{l}\text { Poor } \\
\text { relaxation }\end{array}$ \\
\hline L. Cervical paraspinals & Spinal & $\begin{array}{l}\text { C4- } \\
\mathrm{C} 8\end{array}$ & $\mathrm{~N}$ & None & None & None & None & $\mathrm{N}$ & $\mathrm{N}$ & $\mathrm{N}$ & $\mathrm{N}$ & $\begin{array}{l}\text { Poor } \\
\text { relaxation }\end{array}$ \\
\hline
\end{tabular}

\section{TABLE 2: Needle Electromyography}

Amp $=$ amplitude, Dur = duration, Fasc $=$ fasciculations, Fib = fibrillation, H.F. $=$ high frequency, IA = la fibers, LD/LDP = long duration/long duration potentials, MUAP = motor unit action potential, $\mathrm{N}=$ normal, $\mathrm{PPP}=$ polyphasic potential, $\mathrm{PSW}=$ polyspike wave, RIFP $=$ reduced interference pattern; EMG, electromyography 


\section{Cureus}

\begin{tabular}{|c|c|c|c|c|c|}
\hline Nerve/Sites & Peak (ms) & Duration (ms) & Amplitude $(\mu \mathrm{V})$ & Distance (cm) & Velocity Peak (m/s) \\
\hline \multicolumn{6}{|c|}{ R Median - Digit II } \\
\hline Wrist & 4.74 & 3.96 & 14.5 & & \\
\hline \multicolumn{6}{|c|}{ R Ulnar - Digit V } \\
\hline Wrist & 3.07 & 2.19 & 15.7 & & \\
\hline B. Elbow & 6.77 & 3.33 & 18.2 & 20 & 54.1 \\
\hline A. Elbow & 8.02 & 4.58 & 17.2 & 7 & 56.0 \\
\hline \multicolumn{6}{|c|}{ R. Median - Ulnar - Palmar } \\
\hline Median & 2.60 & 1.41 & 65.3 & & \\
\hline Ulnar & 1.98 & 1.20 & 62.5 & & \\
\hline \multicolumn{6}{|c|}{ R Sural - Lateral Malleolus } \\
\hline Calf & 2.92 & 2.24 & 21.5 & & \\
\hline
\end{tabular}

\section{TABLE 3: Sensory Nerve Conduction Studies}

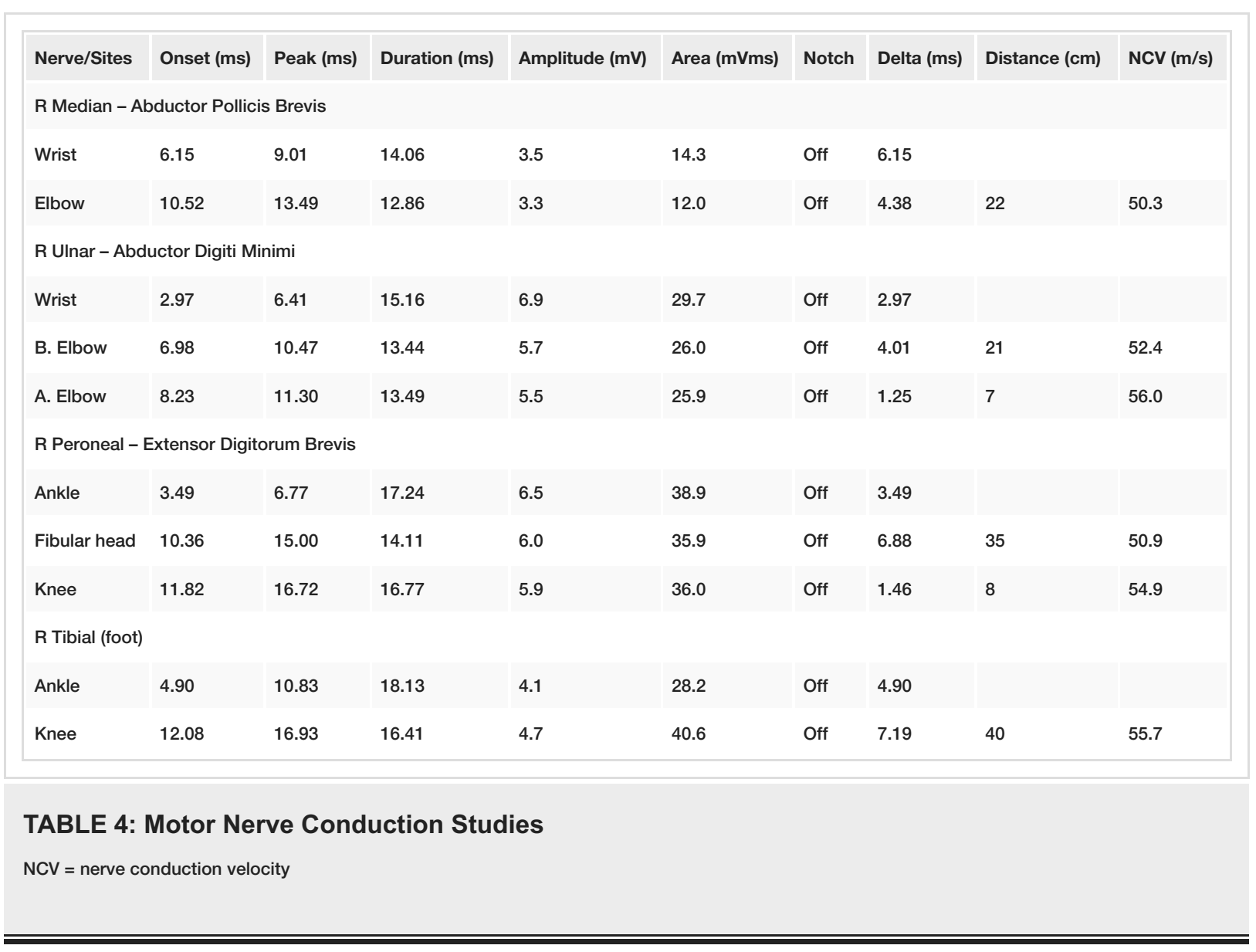




\section{Cureus}

\begin{tabular}{|c|c|c|}
\hline & Reference Range and Units & Result \\
\hline Volume, CSF & $\mathrm{mL}$ & 1.5 \\
\hline Clarity, CSF & & Clear \\
\hline Color, CSF & & Colorless \\
\hline RBC, CSF & $/ \mathrm{mcL}$ & 1 \\
\hline WBC, $\mathrm{CSF}$ & $0-5 / \mathrm{mcL}$ & 4 \\
\hline Lymphocytes, CSF & $40 \%-80 \%$ & 98 \\
\hline Monocytes, CSF & $15 \%-45 \%$ & 2 \\
\hline Differential based on, CSF & Cells & 100 \\
\hline Glucose, CSF & $50-80 \mathrm{mg} / \mathrm{dL}$ & 66 \\
\hline Protein, CSF & $15.0-60.0 \mathrm{mg} / \mathrm{dL}$ & 23.0 \\
\hline Meningitis/encephalitis panel by PCR (CSF) & Negative & Negative \\
\hline West Nile virus AB IgM, CSF & $<=0.89$ IV & 0.02 \\
\hline IgG Monos, GM1 & Negative & Negative \\
\hline IgM Monos, GM1 & Negative & Negative \\
\hline IgG Asialo, GM1 & Negative & Negative \\
\hline IgM Asialo, GM1 & Negative & Negative \\
\hline IgG Disialo, GD1B & Negative & Negative \\
\hline IgM Disialo, GD1B & Negative & Negative \\
\hline
\end{tabular}

\section{TABLE 5: Lumbar Puncture Results}

$\mathrm{CSF}=$ cerebrospinal fluid, $\mathrm{Ig}=$ immunoglobulin, $\mathrm{PCR}=$ polymerase chain reaction, $\mathrm{RBC}=$ red blood cell, $\mathrm{WBC}=$ white blood cell

\section{Discussion}

PTS is a relatively rare diagnosis, with some estimates being as low as 1.64 per 100,000 population [3]. However, given the frequency of under-recognition and misdiagnosis, some have estimated that the true incidence is closer to 20-30 per 100,000 [2]. It is our belief that PTS was triggered in our patient secondary to the vaccine she received, though it is rarely possible to pinpoint a definite etiology. Many associations with PTS have been documented including infection, surgery, anesthesia, rheumatic disease, trauma, stressful exercise, pregnancy, radiation therapy, and vaccination [4]. Based on a thorough history, recent vaccination was the only association present in our patient. Given the lack of family history, our suspicion of hereditary PTS was low, though we cannot rule it out as a contributing factor as no genetic testing was done.

One of the difficult issues with diagnosing PTS is the lack of a reliable confirmatory test. The diagnosis is largely clinical, although there are a few tests, such as EMG, that can support the diagnosis. In the case of this particular patient, her first EMG was done too early to be of diagnostic value for her, as significant abnormalities often do not appear until three weeks after onset in PTS [5]. In most cases, the differential is broad and the history (especially time of onset) may not always be clear, so delaying EMG testing is not always reasonable. As suggested by this case, threshold for a repeat EMG in patients with persistent, recurrent, or worsening symptoms without a diagnosis should be low.

Evidence of effective treatment is limited, and significant spontaneous resolution is eventually seen in most patients, but one study suggests that oral prednisone given within the first month may shorten the painful interval and accelerate recovery in some patients [6]. In our patient, 38 weeks passed before the diagnosis was established, which was well beyond the suggested therapeutic window for prednisone mentioned above. This is actually shorter than the mean time of 43.8 weeks for diagnosis according to one review, although the median was significantly shorter at 10.5 weeks [2].

We treated this patient with IVIG and prednisone. There is no strong evidence as to how a patient with PTS should be treated in the chronic phase, but there is reported efficacy in case reports from the use of IVIG 
In the acute phase, the pain is often so intense that it is necessary to treat with opiates, tricyclics, or antiepileptic drugs [13]. In the case of this patient, the pain had already resolved spontaneously, so there was no indication for pain management.

We also referred this patient to physical therapy, which is utilized for both range of motion and strengthening. Caution must be used in early reinnervation stages, as overloading injured muscles can retard axonal regeneration and muscle reinnervation [4]. Limited EMG follow-up testing may be utilized to demonstrate the extent of reinnervation and guide advancement of strengthening regimen, but is not absolutely necessary [4].

Although the diagnosis of PTS was significantly delayed in this patient, this does not necessarily mean that the suspicion of a functional disorder was incorrect. Functional disorders may be diagnosed based on positive findings, such as Hoover's sign, drift without pronation, giveway weakness, and so on, and are not always a diagnosis of exclusion. With this in mind, it is important to consider that a patient may display these positive findings as part of a functional overlay to an organic neurologic disorder [14].

\section{Conclusions}

In a patient presenting with shoulder pain followed by weakness, PTS should always be included in the differential diagnosis, especially if the initial workup does not reveal an obvious etiology. PTS is primarily a clinical diagnosis, and EMG findings are often unrevealing in the acute phase (up to three weeks). A functional disorder, even when correctly diagnosed secondary to positive findings as mentioned in the discussion, does not exclude an underlying organic neurologic disorder. In some cases, an organic neurologic disorder may even be considered a risk factor for a functional disorder. Current treatment options for PTS are limited, but there is evidence that oral prednisone within the first month may be beneficial, so a timely diagnosis is of increased importance. Given that EMG findings may not be apparent until three weeks after symptom onset, the threshold for ordering a repeat EMG should be low in patients without a strong diagnosis.

\section{Additional Information \\ Disclosures}

Human subjects: Consent was obtained by all participants in this study. Conflicts of interest: In compliance with the ICMJE uniform disclosure form, all authors declare the following: Payment/services info: All authors have declared that no financial support was received from any organization for the submitted work. Financial relationships: All authors have declared that they have no financial relationships at present or within the previous three years with any organizations that might have an interest in the submitted work. Other relationships: All authors have declared that there are no other relationships or activities that could appear to have influenced the submitted work.

\section{References}

1. van Alfen N: Clinical and pathophysiological concepts of neuralgic amyotrophy. Nat Rev Neurol. 2011, 7:315-322. 10.1038/nrneurol.2011.62

2. van Alfen N, van Engelen BG: The clinical spectrum of neuralgic amyotrophy in 246 cases . Brain. 129:438450. 10.1093/brain/awh722

3. Beghi E, Kurland LT, Mulder DW, Nicolosi A: Brachial plexus neuropathy in the population of Rochester, Minneosta, 1970-1981. Ann Neurol. 1985, 18:320-323. 10.1002/ana.410180308

4. Feinberg JH, Radecki J: Parsonage-turner syndrome. HSS J. 2010, 6:199-205. 10.1007/s11420-010-9176-x

5. Ortiz Torres M, Mesfin FB: Brachial Plexitis (Parsonage Turner Syndrome, Brachial Neuropathy, Brachial Radiculitis). StatPearls Publishing, Treasure Island, FL ; 2019.

6. van Alfen N, van Engelen BG, Hughes RA: Treatment for idiopathic and hereditary neuralgic amyotrophy (brachial neuritis). Cochrane Database Syst Rev. 2009, 3:CD006976. 10.1002/14651858.CD006976.pub2

7. Johnson NE: Rapid resolution of severe neuralgic amyotrophy after treatment with corticosteroids and IVIg . Muscle Nerve. 44:304-305. 10.1002/mus.22100

8. Moriguchi K, Miyamoto K, Takada K, Kusunoki S: Four cases of anti-ganglioside antibody-positive neuralgic amyotrophy with good response to intravenous immunoglobulin infusion therapy. J Neuroimmunol 238. 107:109. 10.1016/j.jneuroim.2011.08.005

9. Morishima R, Nagaoka U, Nagao M, Isozaki E: Chronic brachial plexus neuritis that developed into typical neuralgic amyotrophy and positively responded to immunotherapy. Intern Med. 201, 57:1021-1026. 10.2169/internalmedicine.9482-17

10. Naito K, Fukushima K, Ikeda S, et al.: Intravenous immunoglobulin (IVIg) with methylprednisolone pulse therapy for motor impairment of neuralgic amyotrophy, clinical observations in 10 cases. Intern Med. 2012, 51:1493-1500. 10.2169/internalmedicine.51.7049

11. Nakajima M: Partial but rapid recovery from paralysis after immunomodulation during early stage of neuralgic amyotrophy. Euro Neurol. 2006, 55:227-229. 10.1159/000093875

12. Nomoto N, Konno S, Murata M, Nakazora H, Nemoto H, Fujioka T: Case of neuralgic amyotrophy with anti GT1a antibody. Rinsho Shinkeigaku. 50:415-417. 10.5692/clinicalneurol.50.415 


\section{Cureus}

13. Al Khalili Y, Jain S, DeCastro A: Brachial Neuritis. StatPearls Publishing, Treasure Island, FL ; 2019.

14. Stone J, Reuber M, Carson A: Functional symptoms in neurology: mimics and chameleons. Pract Neurol. 2013, 13:104. 10.1136/practneurol-2012-000422 